\section{雨水排出用の溝に発生した セスジユスリカの生態}

$$
\text { 桑田一男 }
$$

セスシュスリカ(Chi ronomus dorsalis Mei一 gen）は北半球に広く分布する中型のユスリカで, 我が 国でる至る所飞極めて普通飞産する。

演者は松山市内の学校内の校舎の周冊につくられたコ ンクリート製雨水排出用の溝 (幅 $21 \mathrm{~cm}$, 深さ $13 \mathrm{~cm}$ ) 飞発生したセスシュスリカの生息状態（主として幼蛙の 個体数と垿化数の変動)を本年（1965 年）6月から観 察してきた。

一般に完全な雨水排出用の溝は降雨の際にのみ水が流 れ，それ以外の時はほとんど乾燥しているのが普通であ る。ところがこの溝は構築後約 30 年過っているために 中央部が沈下していたり, 地表からの土砂の流入のため 飞水がたまりやすくなっていること，扰よ゙溝の近くに ある水生植物载培用の pond から常時少量の清水が流れ こむことによってはとんど年中水がたまっている。

\section{活性活泥菌体量の測定}

\section{1 緒 䡒須藤隆一 杉本一次 寺沢克夫}

活性污泥濃度を湘定する方法としては 30 分沈渐後の 容量 (\%), MLSS (Mixed Liquor Suspended Solid)あるいはMLVSS(Mixed Liquor Volatile Suspended Solid)の值が使われ, 特飞MLVSS が活性污泥の微生物量を示すといわれている。しか しながら活性污泥の代謝の研究や余剩污泥の推定には微 生物の乾燥重量の測定法あるいは, 間接的飞微生物量を 示す測定法の確立が必要のよう沉思われる。

活性污泥は周知の通り細菌や原生動物などの微生物の 增殖によって形成された集合体であるが主体は細菌であ る。都市下水の活性污泥の場合, 無生物の固形粒子が相 当量エアーションタンクに流入し、これらが微生物と共 存するので活性污泥の乾燥重量の測定值が微生物の乾燥 重量を示すといらかけにはいかない。また，熱枃堿量も 微生物体中の灰分量を無視することになるのでこれる妥 当ではない。

細菌は普通蛋白質 $40 \sim 50 \%$, 核酸 $13 \sim 25 \%$, 脂質 $10 \sim 15 \%$ 含をのて，これらを測定しても微生物量を 推定することはできる。

Gaudy 等は活性污泥微生物の固形分当りの COD值 は基質や菌令飞関係なく一定であり, 活性污泥の C OD
幼虫は赩で老熟したすのは体長 16 mm内外飞達し， 泥をもちいて筒宩をつくる。6月上旬には溝全体で約 170,000 個体が生息しており, 生息密度は底泥面積 $1 \mathrm{~cm}^{2}$ あたり 2〜 15 個体であった。観察した期間内ではこの 時か最も多かった。その後降雨飞上る土砂流入のために水 がせき止められたり，7 月下够からの睛天続きのため干 、上ったりしたため 8 月中旬化は幼虫の生息範囲は 6 月 上旬のそれの約专にせばまり, 生息密度は約 $\frac{1}{3}$ て低下し ている。軼化数については 24 時間単位て調べた結果 6 月上・中旬が多く（水面の面積 $0.1 \mathrm{~m}^{2}$ あたり平均 80 個


は 20 個体内外の日が多く, 8 月中旬では 10 個体内外 である。

はげしい降雨は幼虫の生活に少なから奴影響をあたえ， 成虫の粰化をいちじるしくさまたげる。

この溝には本種のほかにヒメモノアラガイ, ミシンコ, イトミミズモンコユスリカなどの水生動物や接合藻の アオミドロ，アミミドロがみられる。7 月下旬からアオ ミドロが增えはじめ水中に広がったために躬化が防害さ れているよ5である。

值を利用すると活性污泥法に打けるほほ $100 \%$ 近いエネ ルギー収支を得るととができると報告している。

筆者等は種々の活性污泥飞ついて乾燥重量当りのC O $\mathrm{D}$ ，炭水化物，蛋白質などを湘定したのでこに報告す る。

\section{2 実験方法}

(1) 人工下水

2 種類の人工下水を使用しその組成は下記に示した 通りである。

(A) ペプトン

肉エキス

尿素

塩化ナトリウム

リン酸ニナトリウム

塩化カリウム

塩化カルシュウム

69

48

18

0.38

18

0.148

0.148

硫酸マグネシュウム

0.18

蒸留水

$1,000 \mathrm{~m} \ell$

(B) クルコース

13338

塩化アンモニウム

1898

塩化ナトリウム

0.38

リン酸ニナトリウム

18

塩化カリウム

0.148

0.148

$0.1 \%$

硫酸マグネシウム

$1,000 \mathrm{ml}$ 
なお，〔A〕は最も一般に使用される組成であり，(B] は塩類を〔A]と同し組成にし，栄美源にクルコースを

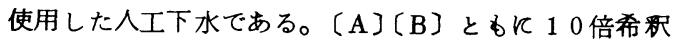
すると B OD約 $1,000 \mathrm{ppm} ， 20$ 倍飞希粎すると B O D 約 $500 \mathrm{ppm}$ Кなる。

(2) 活性污泥

人工下水による活性污泥の熟成に使用した連続曝気装 置を第 1 図に示した。人工下水を眝留槽 (A) から導水 マイクロポンプ（B）を通してエアレーションタンク(C) に送り,さらに沈澱槽 (D)飞連続させ, 処理水性眝留槽 (E) 飞流出さ壮る。返送污は沈澱槽の底部からマイクロ ポンプによって(C)反杘す。架気はマイクロコンプレッ サーから送風計を通して $3 \ell /$ 分の割合で送り，道水は $700 \mathrm{ml} /$ 時間の割合 ( 6 時間曝気) で行ない，またエア レーションタンクの水温は $20^{\circ} \mathrm{C} \pm 1.5^{\circ} \mathrm{C}$ 亿保持した。

曝気開始時飞は実際槽の都市下水の活性污泥を約 200 $\boldsymbol{m} \ell$ 植種し, 約 5 日間以上の操作を続けたのち, エアレー ションタンク内の污泥を採取した。

実際槽の活性污泥は散気式のエアレーションタンクの 最終回路で採取した。

\section{(3) 測定方法}

採取した活性污泥混合液は $2000 \mathrm{ppm}$ で 5 分間遠沈 し，上澄液を捨て，0.05 Mリン酸緩衝液を加えてよく洗 净して再び遠沈し, この操作を 2 回繰り返しリン酸楥衝 浓に懸濁させ，これを試料とした。

乾燥重量の測定にはポアサイズ $0.45 \mu$ のミリポアフイ ルターを使用した。

$\mathrm{COD}$ 值は重クロム酸カリ法 (下水試験法) 飞従い還 流時間は 2 時間とし, 分析值は乾燥重量 1 mgr対応する C O D mgで示した。一方, 炭水化物はアンスロン法によ って測定した。また蛋白質はケルダール法とビニレッ ト法によったが、ビュレット法は良好な結果が得られな かったので主としてケルダール法にょって窒素を求め,

窒素含量を $16.5 \%$ と仮定して蛋白量を算出した。炭水化 物と蛋白質は乾燥重量中の割合（\%) で示した。測定値 は一試料で 2,3 回行ない, 結果にはその平均值を示し た。

なお，実際槽の活性污泥飞ついてのみ下水圾験方法に よってMLVSSを測定した。

\section{3 結 果}

（1）人工下水〔A〕のBOD $500 \mathrm{ppm}$ を導水してBOD 負荷 $0.59 \sim 0.87 \mathrm{~kg} / \mathrm{MLSS} \mathrm{kg} / \mathrm{day}$ の範囲での活性污 泥について得られた結果を第 1 表に示した。

C O D は乾燥重量 $1 \mathrm{mg}$ で最低 $1.24 \mathrm{mg}$, 最高 $1.3 \mathrm{gmg}$ 平均 $132 \mathrm{mg}$ となり, 炭水化物は乾燥重量中最低 $7.8 \%$, 最高 $10.2 \%$ ，平均 $90 \%$ となった。また蛋白質は最低 $54 \%$,
最高 $65 \%$, 平均 $61 \%$ 㨽定された。

第 1 表の下部に示した 3 試料は，本条件で得られた活 性污泥を24時間道水なしに曝気処理した污泥の測定値 である。 $\mathrm{COD}$ 平均 $1.35 \mathrm{mg}$, 炭水件物 $7.6 \%$, 蛋白質 $58 \%$ となり曝気処理前と大差ない結果になった。

（2）人工下水〔A]のBOD 1,000 ppm を道水し，B $\mathrm{O}$ D負荷 $1.12 \sim 1.81 \mathrm{~kg} / \mathrm{MLSS} \mathrm{kg} / \mathrm{day}$ である活性污 泥の結果を第 2 表に示した。

CO Dは1.26 1.40mgで平均 $1.33 \mathrm{mg}$, 炭水化物は $5.4 \sim 83 \%$, 平均 $7.0 \%$, 蛋白質は $56 \sim 73 \%$, 平均 $66 \%$ になった。CODと炭水化物では(1)の実験 とほほ 同様であったが，蛋白質はや>増加が認められた。

（3）第 3 表飞人工下水〔B]の $500 \mathrm{ppm}$ を送り，B OD負荷が $0.65 \sim 1.0 \mathrm{~kg} / \mathrm{MLS} \mathrm{Skg} / \mathrm{d}$ a y の範囲にある活 性污泥の結果を示した。CODは131〜1.40 mg, 平均 $1.34 \mathrm{mg}$, 炭水化物 $11.6 \sim 15.2 \%$, 平均 $13.8 \%$, 蛋白 質 $32 \sim 49 \%$, 平均 $43 \%$ 亿なり，(1)，(2)の分析值に比 較して炭水化物の増加及び蛋白質の减少が認められた。 しかしながら，COD D值は変化を示さなかった。

（4） 1,000 p pmの人工下水 [B] の送水炕より熟成し た活性污泥の結果を第 4 表に示した。このときのエアレ ーションタンクのBOD負荷は $129 \sim 178 \mathrm{~kg} / \mathrm{MLSS}$ $\mathrm{kg} / \mathrm{d}$ ay である。C O Dは $129 \sim 1.44 \mathrm{mg}$ で平均 137 $m g$, 炭水化物は $120 \sim 21.5 \%$, 平均 $17.3 \%$ 蛋白質は $39 \sim 61 \%$ 平均 $48 \%$ \%なり, 炭水化物は(3)の分析值よ りも增加し(1)，(2)の 2 倍以上の含有量を示しだが，００ Dには変化を認めることはできなかった。

（5）実際槽で探取した活性污泥（BOD負荷015〜 0.20 $\mathrm{kg} / \mathrm{ML} \mathrm{SS} \mathrm{kg} / \mathrm{day})$ 飞ついて上記と同样に測定を行な い第 5 表に示した。同時にMLVSSを測定し（）内に MLVSS 飞対応する値を付記した。なおこの活性污泥の ML VSS /乾燥重量 (MLSS) の值は 54 〜 $63 \%$ ある。 乾燥重量当りのC ODは $0.83 \sim 112 \mathrm{mg}$ 平均 $0.93 \mathrm{mg}$ 炭水化物は $5.6 \sim 124 \%$, 平均 $90 \%$, 蛋白質は $21 \sim$ $35 \%$, 平均 $30 \%$ であり, MLVSS当りの平均値は $\mathrm{C}$ O D $1.58 \mathrm{mg}$,炭水化物 $15.2 \%$, 蛋白質 $48 \%$ とい5結果 が得られた。

\section{4 考寀}

以上報告したように活性污泥中の炭水化物と蛋白質含 量は基質や操作条件の相違によってかなりの変動が認め られたか，人工下水によって熟成した活性污泥の乾燥重 量飞対応する COD值は基質の種類や操作条件飞関係な くほとんど一定で, 全測定值の平均值は乾燥重量 $1 \mathrm{mgrc}$

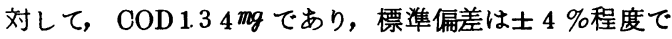
あった。

活性污泥の実験式は細菌と同式の $\mathrm{C}_{5} \mathrm{H}_{7} \mathrm{NO}_{2}$ が一般に 
使用されており，本式が妥当であるとすれば

$\mathrm{C}_{5} \mathrm{H}_{7} \mathrm{NO}_{2}+5 \mathrm{O}_{2}=5 \mathrm{CO}_{2}+\mathrm{NH}_{3}+2 \mathrm{H}_{2} \mathrm{O}$

となり，CODは細胞重量の 1,41 4倍になるはずであ る。

本実験で得られたＯD值は細胞重量の 134 倍である から理論値つ 141 倍をやや下迥った数値になった。

Gaudy 等はクルコースで增殖した菌体のCODは平均 137 倍, ソルビトールでは 131 倍であると報告している がこれる理論量よりはや>低い値である。

実際槽の活性污泥では人下水の活性污泥はど再現性 が高い結果を得ることはできなかったが，それですCOD については炭水化物や蛋白質はど偏差がなく，標準偏差 約士 $10 \%$ で測定できた。

人工下水で得られた乾燥重量 $1 \mathrm{mg}$ で C O D $134 \mathrm{mg}$ か 実際槽の活性污泥にそのまま適応できるすのとすれば乾 嬠重量では0.93mg, MLVSS では 158mgであるから 1.34 吗とはかなりの差があり，乾燥重量，MLVSSともに微 生物の細胞重量を示していないことになる。

このため, 重クロム酸カリ法の CO Dは微生物量を推 定するにはきわめて有効な方法であり，特に代謝の研究 には，役に立つと考えられる。



第 1 表 活性污泥のCOD, Carbohydrate 及び $P$ rote in (人工下水(A] $500 \mathrm{ppm}$ )

\begin{tabular}{|c|c|c|c|}
\hline & COD (mg) & C ar bohydrate (\%) & Prot e i n (\%) \\
\hline 1 & 124 & 84 & 54 \\
2 & 134 & 90 & 65 \\
3 & 131 & 7.8 & 63 \\
4 & 139 & 10.2 & 65 \\
5 & 130 & 97 & 58 \\
\hline 平 均 & 132 & 90 & 61 \\
\hline 1 & 136 & 80 & 59 \\
2 & 132 & 81 & 54 \\
3 & 138 & 6.8 & 60 \\
\hline 平 均 & 135 & 7.6 & 58 \\
\hline
\end{tabular}

\section{5 考文神}

(1) A. F. Gaudy Jr, M. N. Bhat la a and E. T. Gaudy, Use of Chemical Oxygen Demand Values of Bacterial Cells in WasteWater Purification,

Applied Microbiology Vol 12, Na3 ( 1964 )

(2) A. F.Gaudy, J r,

Colorimetric Determination of Protein \& Carbohydrate,

Industrial Water \& Wastes, Vol 7, Na1,

（3）日本水道協会

(1962)

下水試験方法 (1964)

（4）寺沢克夫, 吉野铜, 町田隆彥

活性污泥処理における污泥成について、

下水道協会誌 Vol 2, N16 (1965)

第 2 表 活性污泥の COD, Carbohydrate 及び Prote in (人工下水(A) $1,000 \mathrm{ppm}$ )

\begin{tabular}{|c|c|c|c|}
\hline & C OD (mg) & Car bohydra te (\%) & Prote i n (\%) \\
\hline 1 & 1.26 & 8.1 & 65 \\
2 & 1.27 & 5.4 & 72 \\
3 & 137 & 6.2 & 56 \\
4 & 1.40 & 7.0 & 62 \\
5 & 1.34 & 8.3 & 73 \\
\hline 平 均 & 1.33 & 7.0 & 66 \\
\hline
\end{tabular}

第3表 活性污泥のCOD, Carbohyrate 及び Protein (人工下水(B) $500 \mathrm{ppm}$ )

\begin{tabular}{|c|c|c|c|}
\hline & COD (mg) & Carbohydrate (\%) & Prot e i n (\%) \\
\hline 1 & 134 & 123 & 48 \\
2 & 133 & 116 & 44 \\
3 & 134 & 164 & 32 \\
4 & 140 & 137 & 49 \\
5 & 131 & 152 & 40 \\
\hline 平 均 & 134 & 138 & 43 \\
\hline
\end{tabular}

